\title{
Fertigation for Effective Nutrition and Higher Productivity in Banana - A Review
}

\author{
M. Senthilkumar ${ }^{1}$, S. Ganesh ${ }^{2}$, K. Srinivas ${ }^{1}$, P. Panneerselvam ${ }^{3}$, \\ A. Nagaraja ${ }^{4}$ and B.L. Kasinath ${ }^{5}$ \\ ${ }^{1}$ ICAR-Indian Institute of Horticultural Research, Bengaluru-560089, Karnataka, India \\ ${ }^{2}$ Gandhigram Rural Institute (Deemed University), Gandhigram-624 302, Tamil Nadu, India \\ ${ }^{3}$ ICAR-National Rice Research Institute, Cuttack, Odisha, India \\ ${ }^{4}$ ICAR-Indian Agricultural Research Institute, New Delhi, India \\ ${ }^{5}$ ICAR-Central Island Agricultural Research Institute, Port Blair, Andaman \& Nicobar \\ *Corresponding author
}

\section{A B S T R A C T}

Banana is a highly exhaustive crop which requires large quantities of mineral nutrients for rapid growth and development, thus it readily responds to applied nutrients. Major nutrients like nitrogen, phosphorus and potassium play an important role in the vegetative and reproductive phases of crop growth, depending on the cultivar. In general, the input

\section{Keywords}

Banana, Nutrients, Dripirrigation, Fertigation, Yield, Quality.

Article Info

Accepted:

21 June 2017

Available Online:

10 July 2017 use efficiency of various nutrients used for crop growth and development is currently very low leading to problems of decreased productivity, degradation of soil health and increased environmental pollution apart from the wastage of substantial quantity of costly and scarce inputs. Increasing the efficiency of water and fertilizer can itself go a long way in realizing the growing demand for food and other plant products. These multiple requirements led to adoption of fertigation, which very much improves the nutrient uptake efficiency to an extent of 30-40 per cent, prevents soil degradation, reduces the cost of fertilizer and application besides improving the productivity and quality of the produce. Fertigation also minimizes the pollution of ground water by preventing losses through run off and Leaching. The fertigation results in saving water consumption to an extent of 40-70 per cent and fertilizer use to 25 per cent. The fertilizer application should contain more of potassium and nitrogen. Similarly, the choice and dosage of nutrients, time, mode and frequency of application vary depending on the cultivars, initial soil fertility, the production system and agro climatic conditions. Banana requires heavy manuring near by the soil surface because of its shallow rooting nature. Most of the researchers suggested weekly fertigation with water soluble fertilizers for higher productivity.

\section{Introduction}

India is the largest producer of banana in the world contributing 25.60 per cent to the global production, with 26.51 million tonnes from an area of 0.77 million ha. Among the fruit crops, banana enjoys a special status in India with a major share of 11.11 per cent in the area and 32.6 per cent of the production (Anonymous, 2013). Availability of huge genetic diversity, varying production systems and suitability to wide range of agro climatic conditions has attributed to its large-scale cultivation. It is grown both as homestead 
garden plant as well as commercial plantation. However, the total production is largely consumed domestically and has negligible share in the global trade. Among the horticultural crops, banana contributes 1.99 per cent to Agricultural Gross Domestic product (GDP) (Singh, 2007).

Though several commercial varieties of bananas are grown all over the world, the Cavendish groups of banana viz., Grand Naine, Williams and Robusta are grown extensively owing to comparatively higher yield potential compared to other cultivars of banana and better marketability both in domestic and export markets (Mustaffa and Kumar, 2012). Among the major banana growing states in India, Tamil Nadu has the largest area (1.11 lakh $\left.\mathrm{ha}^{-1}\right)$ followed by Karnataka (0.92 lakh ha ${ }^{-1}$ ) and Maharashtra (0.82 lakh ha-1). Tamil Nadu ranks first in production (51.36 lakh tonnes) followed by Gujarat (45.23 lakh tonnes), whereas Gujarat leads in productivity (64.1 tonnes $\left.\mathrm{ha}^{-1}\right)$ followed by Tamilnadu (46.10 tonnes $\mathrm{ha}^{-1}$ ) (Anonymous, 2013).

Banana is a highly exhaustive crop, readily responds to applied nutrients (Mustaffa and Kumar, 2012) therefore requires large quantities of mineral nutrients (Raghupathi et al., 2000; Noor et al., 2010) for rapid growth and development. Major nutrients like nitrogen, phosphorus and potassium play an important role in the vegetative and reproductive phases of crop growth, depending on the cultivar. For better growth and yield of banana, optimum levels of nutrients have to be maintained which are often supplied partly by the soil (Swennen, 1990) and the remaining through some other alternative sources such as inorganic fertilizers and bio-inoculants.

The nutrient uptake studies conducted in different countries showed that a crop yielding 46-60 tonnes $\mathrm{ha}^{-1}$ utilizes nearly 250-
$300 \mathrm{Kg}$ of $\mathrm{N}, 25-40 \mathrm{~kg}$ of $\mathrm{P}$ and $800-1000 \mathrm{~kg}$ of $\mathrm{K}, 150-180 \mathrm{~kg}$ of $\mathrm{Ca}$ and $40-60 \mathrm{~kg}$ of $\mathrm{Mg}$ $\mathrm{ha}^{-1}$. Similarly, Wichmann (1992) reported that the total nutrient uptake in banana (Cavendish group) varies from 4-7 kg N, 0.9$1.6 \mathrm{~kg} \mathrm{P}$ and $18-30 \mathrm{~kg} \mathrm{~K}$ tone $^{-1}$ of whole bunches produced whereas, Rivera (2004) reported that a 20 kilo bunch removes $44 \mathrm{~g}$ of $\mathrm{N}, 5 \mathrm{~g}$ of $\mathrm{P}$ and $143.47 \mathrm{~g}$ of $\mathrm{K}$. In India, though a wide range of fertilizer recommendations are in vogue, a blanket application of 200: 120: 250 NPK along with $15 \mathrm{~kg}$ of farmyard manure plant ${ }^{-1}$ is recommended in the state of Karnataka (Radha and Mathew, 2007).

Among the nutrients, $\mathrm{N}$ is the most essential element and has a positive influence on plant growth, flowering and productivity in banana cultivars (Mustaffa and Kumar, 2012). Though the requirement of phosphorous is low, it helps to produce healthy rhizome, strong root system and prevents lodging. It also plays a vital role in overall development of the plant and flower set. The plant can store $\mathrm{P}$ longer and can utilize it for fruit production and development. Another element of high importance for growth of banana is potassium (Lopez and Espinosa, 1998). It is commonly known as "quality mineral nutrient" and its requirement is very high during the flowering period. Its concentration in the plant system is much higher than all other nutrients, or even all the mineral nutrients combined. Supply of K fertilizers in adequate quantity not only increases growth and yield in banana, physiology of the plant and offers resistance against biotic and abiotic stresses (Mustaffa and Kumar, 2012). It is also known for stimulating early shooting, increasing number of hands, finger size, quality and sweetness apart from increasing the keeping quality, and reducing the total water uptake (Radha and Mathew, 2007).

Hence, the fertilizer application should contain more of potassium and nitrogen 
(Santos et al., 2009), the choice and dosage of nutrients, time, mode and frequency of application vary depending on the cultivars, initial soil fertility, production system and agro climatic conditions. In general, the input use efficiency of various nutrients used for crop growth and development is currently very low leading to problems of decreased productivity, degradation of soil health and increased environmental pollution apart from the wastage of substantial quantity of the costly and scarce inputs. Increasing the efficiency of water and fertilizer will go a long way in realizing the growing demand for food and other plant products vis-a-vis the rapidly escalating population (Solaimalai et al., 2005). In the conventional method of fertilizer application, there is a considerable loss of nutrients through leaching, evaporation and volatilization. The diminishing land:man and water:man ratios, increasing fertilizer prices, haunting energy crisis, wide spread pollution and fast depletion of natural resources further emphasis the need for improved water and fertilizer use efficiency (Solaimalai et al., 2005).

These multiple requirements forced to adopt fertigation, which facilitates the application of solid or liquid mineral fertilizers through drip irrigation systems thus supplying nutrients containing irrigation water to the crops. Fertigation is becoming popular in banana plantations and the benefits include early flowering, high production per unit area with improved quality (Hegde and Srinivas, 1991). The fertigation has resulted in saving water consumption to an extent of 40-70 per cent and fertilizer use to 25 per cent (Magar and Bhambure, 2000; Srinivas et al., 2001, Mahalakshmi et al., 2001).

In fertigation, the nutrient use efficiency could be as high as 90 per cent compared to 40-60 per cent in conventional methods. The amount of fertilizers lost through leaching is as low as 10 per cent in fertigation whereas, it is 50 per cent in the traditional system of cropping (Sivanappan, 1985). It permits application of a nutrient directly at the site of active roots as required by the crop. Scheduling fertilizer applications on the basis of need, offers possibility of reducing the losses of nutrient elements associated with conventional application methods (Solaimalai et al., 2005). Fertigation is the most effective and convenient means of maintaining optimum fertility level and water supply according to the specific requirement and the savings in the use of fertilizers can be to the tune of 25-50 per cent (Haynes, 1985).

It is estimated that by 2020 , to achieve the targeted production of 321 million tonnes of food grain, the requirement of nutrient will be 28.8 million tonnes, while their availability will be only 21.6 million tonnes causing a deficit of about 7.2 million tonnes. Similarly, the total requirement of horticulture produce was around 300 million tonnes till the end of XI plan period and this is expected to be 600 million tonnes 2020 (Choudhary, 2008). With a production of 240.53 million tonnes of horticultural produce from an area of 21.83 million ha, horticulture is expected to play a dominant role in the overall development of agriculture in the country (Anonymous, 2013).

The above predicted demand for horticultural produce gives an indication that each gram of manure, fertilizer and every drop of water have to be systematically and meticulously utilized to maximize the production per unit area.

Among the major tropical fruit crops, the productivity of Banana per unit area is high (34.2 tonnes $\mathrm{ha}^{-1}$ ). However, there is lot of potential to increase the productivity level considerably as the land area under banana is 
around 11.11 per cent of the total fruit area in India. Even if this productivity is doubled from the present production of 26.51 million tonnes from an area of 0.77 million ha, it will be an appreciable addition to the fruit bowl of the country to meet the fruit demand considerably. Though, the advantage of fertigation has been demonstrated in several horticultural crops including banana (Srinivas, 1997) it is high time to relook the advancements took place and the works carried out in Banana with fertigation will further help refining the production technologies including precision of fertilizer dosage through fertigation to increase the production and productivity of banana.

\section{Fertigation: Scope and role in crop production}

Fertigation refers to the application of solid or liquid mineral fertilizers via pressurized irrigation systems, thus forming irrigation water containing nutrients (Magen, 1995). In a true sense, it is precisely a method of slow application of water and fertilizer in the form of discrete continuous drops, trickled / sprayed through mechanical device called emitters into the root zone of the plant according to its consumptive use and demand. This technique was first started in the late 1960's in Israel (Goldberg and Shimueli, 1970; Magen, 1995; Sneh, 1995) and in the year 1970 Arscott first reported that urea applied through irrigation system was more efficient than hand broadcasting on soil surface on banana. By 1980, over one million hectare was brought under drip irrigation. After few decades, it became a hi-tech, efficient and a potential method in modern agriculture resulting in higher yields with improved quality of the crop produce.

It was proved by many workers that fertilizers applied through broadcasting were not efficiently utilized by plants. On the other hand fertigation ensures application of fertilizers directly to root zone, resulting in higher fertilizer use efficiency. Application of fertilizers through drip irrigation water are more useful in Indian agro climatic condition where most of the orchards are established on sloppy land under rain fed conditions (Naira et al., 2012).

Fertigation in a way can be compared with spoon feeding to plants. It ensures supply of plant nutrients to the root zone along with micro irrigation system. The joint use of fertigation techniques and drip irrigation offers the possibility to optimize the water and nutrient distribution over time (high frequency) and space (precise placement into the active root zone (Nanda, 2010). In the fertigation process, pre dissolved soluble fertilizers are injected into the feeder line of drip system and made available to the plants (Thangaselvabai et al., 2009). Soluble fertilizers can be applied directly to the root zone, tuned in accordance with the need of the crop at different growth stages with a systematic scientific basis.

Further, application of fertilizers through drip irrigation system (fertigation) can reduce fertilizer usage, minimize leaching by rain and excessive irrigation, maximize the fertilizer use efficiency, allows flexibility in timing of fertilizer application, and reduces the labour required for applying the fertilizer (Brad Lewis, 2001). Fertigation technique makes it possible to irrigate and fertigate over a large area in a more uniform and efficient manner than the conventional method of soil application.

Fertigation also greatly improves the nutrient uptake efficiency to an extent of 30-40 per cent, prevents soil degradation, and reduces the cost of fertilizer and application. In another study, 25 per cent higher water and fertilizer use efficiency was obtained in the 
drip fertigated plot as compared to check method of irrigation and fertilizer application through soil (Badgujar et al., 2004, Kumaran and Muthuvel, 2009).

Fertigation can save 20 to 30 per cent of fertilizers, besides improving the yield and quality as compared to the conventional methods of fertilizer application (Mustaffa and Kumar, 2012). Teixeira et al., (2011) reported that fertigation resulted in 36 per cent higher nutrient use efficiency compared to conventional fertilization, for either nitrogen or potassium.

Fertigation minimizes the pollution of ground water by preventing losses through run off and Leaching. It also improves the productivity and quality of the produce (Srinivas, 1997; Mahalakshmi et al., 2001; Pandey et al., 2001). Nanda (2010) obtained 60 to 70 per cent higher yield through drip fertigation with water soluble fertilizers (WSF) in banana as compared to soil application of conventional fertilizers.

The fertilizer use efficiency was also increased up to 67 per cent over conventional fertilizers. The Incremental Cost Benefit Ratios (ICBR) vis-à-vis farmer practices was worked out to be highly encouraging and is 1:6.5 in banana through adoption of fertigation.

\section{Role of fertigation in banana}

Drip fertigation system economizes the use of fertilizers, saving of 35-52 per cent fertilizer compared to conventional cultivation (Ashokkumar et al., 2007) and water ranging from 40 to 60 per cent. Fertilizer use efficiency was increased up to 67 per cent over conventional fertilizer application. Fertigation with water soluble fertilizers in banana increased the yield by 60 to 70 per cent as compared to soil application of conventional fertilizers (Nanda, 2010). Forty per cent saving in fertilizer was achieved without the reduction in banana yield (Solia $e t$ al., 2010).

As Banana is considered as perennial crop, it is highly amenable for fertigation technique. In Hawaii, shifting to drip irrigation combined with fertigation in banana in a well-managed, conventional sprinkler irrigated plantation has doubled the yield (Young et al., 1985). Lahav and Kalmar (1988) opined that banana responded well to drip fertigation. More yield and significantly higher number of hands bunch $^{-1}$ were obtained through fertigation (Smith, 1991 and 1992; Guerrero and Gadbau, 1996). In India also, higher yield with improved quality through fertigation was reported as early as by Hegde and Srinivas (1991); Srinivas, (1997); Srinivas et al., (2001); Mahalakshmi et al., (2001)

\section{Fertigation scheduling}

The real success of any fertigation programme mainly depends upon the systematic scheduling of fertigation as the frequency plays a critical role in fulfilling the requirement of the crop growth and development. In banana it is expected that application should coincide with the climatic conditions, phenological stages (Shahar and Achilea, 1997) and the crop nutrient requirement at various stages. Frequency of fertigation also depends on the type of soil, rainfall pattern and weather conditions, nature of nutrients, etc.

Light soils with low fertility in high rainfall regions require frequent applications. Intensive leaching areas require immediate fertigation. $\mathrm{N}$ and $\mathrm{K}$ fertilizers are applied at short intervals over long period of time (eight times) while $\mathrm{P}$ fertilizers should be applied once or twice manually due to its limited mobility in soil (Robinson, 1996). 
Mahalakshmi et al., (2003) emphasized the timing and regular frequency of the fertigation. They were of the opinion that, high levels of $\mathrm{N}$ and $\mathrm{K}$, particularly $\mathrm{K}$, during the vegetative stage, floral initiation and differentiation increased the yield in cultivar Robusta. They also recorded heaviest bunches (36.5kg as compared to $20.5 \mathrm{~kg}$ in the control) with highest level of irrigation and fertigation at weekly intervals.

According to Sathya et al., (2008) frequent application of nutrients through drip system improves the uptake of nutrients through two main mechanisms: 1) continuous replenishment of nutrients in the depletion zone at the vicinity of root interface and 2) enhanced transport of dissolved nutrients by mass flow, due to the higher averaged water content in the medium.

Lahav and Kalmar (1995) opined that there was a constant advantage in most of the parameters through weekly fertigation. It also increased bunch weight by $0.7 \mathrm{~kg}$ and the yield by $2.2 \mathrm{t} \mathrm{ha}^{-1}$ as compared to continuous application.

Similarly Bhalerao et al., (2009) observed that the application of fertilizers at weekly intervals with $75 \%$ recommended dose of fertilizers of $\mathrm{N}$ and $\mathrm{K}$ (44 splits up to 300 days) through fertigation and phosphorous by soil placement recorded higher yield in cultivar Grand Naine besides saving $\mathrm{N}$ and $\mathrm{K}$ fertilizers up to 25 per cent as compared to the conventional methods.

Whereas, Smith and Hoffman (1998) obtained higher mean bunch weight of 33.3 and $29.2 \mathrm{~kg}$ respectively through monthly micro spray or drip fertigation.

\section{Source of fertilizers in fertigation}

As that of the timing of fertigation, source of fertilizers is also important as it is directly linked with the ready availability of nutrients to the crop. A major success of fertigation was reported from the usage of water soluble fertilizers. Kavino et al., (2004) opined that the plants fertigated with water soluble fertilizers exhibited a strong influence on plant morphology in terms of pseudostem height, girth, number of leaves and its area, leaf area index, total number of leaves produced and phyllochron. Application of water soluble fertilizers resulted in higher bunch weight in cultivar Robusta.

Application of water soluble fertilizers @ 450:90:675g NPK plant ${ }^{-1}$ along with 40 liters of water day ${ }^{-1}$ pit $^{-1}$ resulted in earliest cropping and highest yield (Pandey et al., 2001). Dahiwalkar et al., (2004) also obtained highest yield of (67.31 tonnes ha ${ }^{-1}$ ) with $70 \%$ $\mathrm{N}$ and $80 \% \mathrm{P}$ and $\mathrm{K}$ solid soluble fertilizers through drip irrigation in $\mathrm{cv}$. Vasai.

The treatment of $100 \%$ recommended dose of water soluble fertilizers was found to be significantly superior over lesser doses however Deolankar and Firake (2001) found that $100 \%$ recommended dose treatment was on par with $80 \%$ in respect of yield and all yield contributing parameters except number of fruits bunch ${ }^{-1}$.

Among the different fertilizers, the plant height and bunch weight were increased significantly by fertigation of water soluble fertilizer than straight fertilizer.

All these characters increased significantly with the increase of fertilizer levels from $50 \%$ to $100 \%$ and it was higher at $100 \%$ recommended dose of fertilizers (Raskar, 2003).

In another comparative study, 100:40:200g N: $\mathrm{P}$ : K plant $^{-1}$ (recommended dose) was applied of which $\mathrm{P}$ and $\mathrm{K}$ were applied in solid form, and only $\mathrm{N}$ (Urea) applied through the drip irrigation performed well in respect of all 
yield attributes and registered 15 per cent higher yield (68.5 tonnes $\left.\mathrm{ha}^{-1}\right)$ and 7 per cent higher net returns in cv. Basarai (Berad et al., 1998).

\section{Responses of banana to fertigation}

\section{Growth parameters, yield attributes and yield}

Higher yield up to 18 per cent over broad casting methods in cultivar 'Williams' was obtained by Achilea (1997). Compared with traditional nitrogen application, drip $\mathrm{N}$ fertigation significantly increased the total mass of plant and fruit yield by 9.5 and 8.0 per cent respectively. A 30 per cent saving in $\mathrm{N}$ fertilizer was also obtained (Deng Lan Sheng et al., 2008).

Srinivas et al., (2001) reported that the plant height, stem girth and number of functional leaves increased with the ontogeny of the crop with increase in $\mathrm{N}$ and $\mathrm{K}$ fertigation up to $200 \mathrm{~g}$ plant $^{-1}$. The fruit yield and yield components also increased markedly up to $200 \mathrm{~g} \mathrm{~N}$ and $\mathrm{K}$ fertigation. Improved growth parameters, higher bunch weight, more number of hands, higher fingers bunch ${ }^{-1}$ and higher finger weight was observed with higher $\mathrm{N}$ and $\mathrm{K}$ fertigation.

Reddy et al., (2002), recorded increased yield in cultivar Robusta with the increase in the fertigation levels and the yield was highest with $200 \mathrm{~g} \mathrm{~N}$ and $\mathrm{K}$, which was on par with $150 \mathrm{~g} \mathrm{~N}$ and $\mathrm{K}$. The soil application of $\mathrm{N}$ and $\mathrm{K}$ recorded lowest yield and it was highest with the application of $\mathrm{N}$ and $\mathrm{K}$ through drip followed by $50 \% \mathrm{~N}$ and $\mathrm{K}$ application by drip and $50 \%$ by soil application.

In Robusta, the plant growth, yield attributes and total yield $\mathrm{ha}^{-1}$ was enhanced by application of $100 \%$ recommended dose of $\mathrm{N}$ and $\mathrm{K}$ through fertigation (Ragupathi et al.,
2002) and application of $100 \mathrm{~g} \mathrm{~N}$ through drip both in main and ratoon increased yield in cultivar Ney Poovan (Srinivas, 1997). Similarly, Mahendran et al., (2013) obtained higher yield through application of $100 \%$ recommended dose of fertilizer through sub surface drip fertigation in cv. Rasthali. Whereas, Sousa et al., (2004) observed that in the first and second production cycle, average fruit mass, average bunch mass and fruit yield were influenced by the potassium and there was no response of these characteristics to nitrogen in 'Grand Naine'.

In general the fertigated plants exhibited improved plant morphology in terms of plant girth, number of leaves at harvest and phyllochron. Crop duration was reduced by fertigation treatment and also resulted in heaviest bunches, number of hands and fruits. Application of $100 \%$ nitrogen fertilizer through drip system improved the bunch weight in cultivar Robusta and quality of fruits (Mahalakshmi et al., 2001).

Ashokkumar et al., (2009) obtained higher yield $\left(95.2\right.$ tonnes $\left.\mathrm{ha}^{-1}\right)$ with $100 \%$ recommended dose through fertigation and application of only $65 \%$ of recommended dose of fertilizers yielded at par with conventional method of fertilizer application with $100 \%$ recommended dose of fertilizers.

Badgujar et al., (2004) observed maximum bunch weight with 3 plants hill ${ }^{-1}$ with $75 \%$ recommended dose of fertilizers of $\mathrm{N}$ and $\mathrm{K}$ through fertigation. Per hectare yield was maximum with 2 plants hill ${ }^{-1}$ given with $75 \%$ recommended dose of fertilizers of $\mathrm{N}$ and through fertigation in cultivar Grand Naine. In conformity, Guerra et al., (2004) reported that fertigation promoted bunch weight and yield, higher than the side dressing fertilization. Even reducing 50\% doses of $\mathrm{N}$ and $\mathrm{K}$ did not affect the yield and quality of banana fruits in cultivar "Prata Ana". 
Amritakhound and Bhattacharya (2010) obtained increased yield, higher bunch weight, hands per bunch, fruits per hand, fruit weight, length, girth and volume at $100 \%$ recommended dose with 0.75 evaporation rate followed by $75 \%$ recommended dose of fertilizer through fertigation in $\mathrm{cv}$. Barjahaji (AAA). In Monthan (ABB), the fertigation treatments resulted in maximum pseudostem height, stem circumference, number of hands and fruits, bunch weight, total leaf area, productivity efficiency and leaf, fruit and pseudostem dry matter and leaf nutrient content (Dineshkumar et al., 2012).

In fertigation, the levels/doses of fertilizers play a significant role in determining the yield attributes and yield. Chandrakumar et al., (2001) observed that, the increase in the $\mathrm{N}$ and $\mathrm{K}$ fertigation levels improved the growth parameters of plants. However, differences beyond $100 \mathrm{~g}$ were not significant.

The positive response of banana to higher potassium application after flowering was also observed. Pinto et al., (2005) opined that Nitrogen was effective for bunch, cluster weight and fruit number, and the best rate was $340 \mathrm{~kg} \mathrm{ha}^{-1}$ for maximum yield (17.43 tonnes $\mathrm{ha}^{-1}$ ), while potassium influenced only the number of fruits by cluster. According to Sanjit Pramanik et al., (2013) the banana yield attributing characters and yield were significantly influenced by different treatments and were superior in plants under drip fertigation compared to those under conventional irrigation. Combined application of irrigation at 60\% CPE and 80\% recommended dose of fertilizer yielded significantly higher 49.2 and 44.1 tonnes $\mathrm{ha}^{-1}$ for plant and ratoon crop, respectively, accompanied by higher water use efficiency resulting in considerable saving of water (41.7 and 40.4 per cent for plant crop and ratoon crop respectively). Highest fruit yield over the conventional irrigation method was obtained for the plant crop (32.5 per cent) and ratoon crop (26.4 per cent) with the same treatment of drip fertigation.

Pawar and Dingre (2013) reported that, 100\% recommended dose of fertilizer through drip as per crop growth stages resulted in 46.22 per cent increase in yield (83.62 tonnes $\mathrm{ha}^{-1}$ ). However, it was on par with $80 \%$ fertigation treatments $\left(79\right.$ tonnes $\left.\mathrm{ha}^{-1}\right)$. The banana fruit yield obtained under $60 \%$ fertigation (68 tonnes $\mathrm{ha}^{-1}$ ) produced 19 per cent more yield as compared to conventional fertilizer application through soil (57.4 tonnes $\mathrm{ha}^{-1}$ ) indicating 40 per cent fertilizer saving due to fertigation.

Senthilkumar et al., (2016) found that 100\% recommended dose of fertilizers through fertigation at weekly intervals from $60^{\text {th }}$ day after planting upto 320 days resulted in 101.06 tons of fruits which were $30 \%$ higher as compared to $100 \%$ recommended dose of fertilizers applied through soil application.

Likewise, Pandit et al., (2011) were also of the opinion that increasing dose of nitrogen and phosphorus resulted with maximum pseudostem height whereas, increasing dose of phosphorus and potash were found suitable for increasing the pseudostem girth and advancing the maturity of banana. However, leaf area, number of finger bunch ${ }^{-1}$ and fruit yield were significantly influenced by the increasing dose of nitrogen and potassium. A fertilizer dose containing medium nitrogen and higher doses of phosphorus and potash enhanced the fruit pulp content with a minimum fruit peel percentage. In cultivar Robusta, Hegde and Srinivas (1989) observed that, the dry matter accumulation increased significantly when nitrogen application was increased from 100 to $200 \mathrm{~g}_{\text {plant }}{ }^{-1}$. The dry weights of leaves and rhizomes followed a similar trend, but that of stems was not affected by nitrogen except at the final 
harvest. The dry weight of fruits was increased significantly when nitrogen application increased from 100 to $200 \mathrm{~g} \mathrm{plant}^{-1}$.

Increasing $\mathrm{N}$ fertilization significantly increased dry matter production (Hegde and Srinivas, 1991). The dry matter accumulation in leaf was highest with $100 \mathrm{~g} \mathrm{~N}$ applied through drip during most of the growth stages in cultivar "Ney Poovan" except at harvest, as it was highest with $300 \mathrm{~g} \mathrm{~N}$ (Srinivas, 1997).

Calcium drip fertigation could significantly promote the biomass of banana (the leaf, root and total biomass). The total biomass increase rate was from 5.78 per cent to 10.59 per cent. At the same time, the root length and root surface area increased significantly under drip fertigation, the increased data were 8.6147.35 per cent and 11.77-28.17 per cent (Deng LanSheng et al., 2012).

They also found that application of $\mathrm{Ca}\left(\mathrm{NO}_{3}\right)_{2}$ by means of fertigation did not influence the leaf numbers, leaf width and pseudostem girth of banana, but there were significant effects on leaf length and pseudostem height.

\section{Fertigation and its effect on quality of banana}

Applying fertilizers through fertigation has substantially improved the quality in banana cultivar Robusta (Mahalakshmi et al., 2001, Senthilkumar et al., 2014b). Application of solid soluble fertilizers (SSF) through drip irrigation recorded the highest pulp to peel ratio and T. S. S as compared to conventional treatments in cultivar Vasai (Dahiwalkar et al., 2004). Similar results were obtained by Senthilkumar et al., 2014b in cultivar Robusta. Pawar and Dingre (2013) also observed improvement in the quality attributes in banana through fertigation as compared to conventional fertilizers.

Application of $100 \%$ recommended dose of fertilizers through sub surface drip fertigation improved quality attributes in Rasthali banana (Mahendran et al., 2013). In Robusta, increasing $\mathrm{N}$ application increased the total soluble solids in the pulp although the effect was significant only in the plant crop. The pulp to peel ratio was not affected by $\mathrm{N}$ fertigation. An increasing level of $\mathrm{K}$ fertilization significantly increased the total soluble solids in the ratoon crop and decreased the pulp to peel ratio (Hegde and Srinivas, 1991). In the cultivar 'Ney poovan' the total soluble solids increased with $\mathrm{N}$ application both under drip fertigation and soil application only up to $100 \mathrm{~g} \mathrm{~N}$ plant ${ }^{-1}$. Likewise the pulp to peel ratio was higher with an application of $100 \mathrm{~g} N$ plant $^{-1}$ (Srinivas, 1997).

Dineshkumar et al., (2012) obtained higher T. S. S. due to $75 \%$ recommended dose of fertilizers through fertigation apart from early flowering and fruit maturity.

Pulp to peel ratio was maximum due to $50 \%$ recommended dose of fertilizers in Monthan (ABB) applied through fertigation. Quality parameters in cultivar Basarai were significantly improved due to application of water soluble fertilizers through drip compared to $\mathrm{N}$ alone through drip.

The pulp to peel ratio and T. S. S. were increased significantly by application of $100 \%$ recommended dose of fertilizer through drip but they were on par with75\% recommended dose of fertilizer. The acidity decreased significantly with increased fertilizer dose and it was maximum under $50 \%$ recommended dose of fertilizer (Raskar, 2003).

The quality parameters viz., pulp to peel ratio and T. S. S were maximum in fertigation treatments and significantly higher in 100\% recommended dose of fertilizers over $60 \%$ 
recommended dose and $40 \%$ recommended dose (Deolankar and Firake, 2001). Lower acidity in the fruits was observed by Guerra et al., (2004) in the fertigation treatments. Further, the quality of banana fruits was not affected even after reducing $50 \%$ doses of $\mathrm{N}$ and $\mathrm{K}$ in cultivar 'Prata Ana'.

Pandit et al., (2011) reported that a fertilizer dose containing medium nitrogen and higher doses of phosphorus and potash enhanced the fruit pulp content with minimum fruit peel percentage. Beside this, higher reducing, sugar and lower non-reducing sugar percentage were found at the combination of 400, 300, 250g NPK plant $^{-1}$.

Senthilkumar et al., 2014b could find higher TSS (10-11 per cent), Total sugars (11 per cent), TSS: Acid ratio (14 to 15 per cent) at $100 \%$ recommended dose of fertilizer (200:110:200 N: P: K g plant ${ }^{-1}$ crop $\left.^{-1}\right)$ through fertigation as compared to soil application.

\section{The various intervals of fertigation as suggested by different earlier} Workers in banana are listed below

\begin{tabular}{|c|c|c|c|}
\hline Reference & Variety & Location & Frequency of application \\
\hline $\begin{array}{l}\text { Lahav and Kalmar } \\
\text { (1995) }\end{array}$ & Williams & Israel & Weekly application \\
\hline $\begin{array}{l}\text { Shahar and Achilea } \\
\text { (1997) }\end{array}$ & -- & $\begin{array}{l}\text { Tropical and } \\
\text { suptropical } \\
\text { regions }\end{array}$ & $\begin{array}{l}\text { Weekly intervals and } 30 \% \mathrm{~K} \\
\text { requirement applied at the time } \\
\text { of bunch initiation }\end{array}$ \\
\hline Achilea (1997) & Williams & South Africa & $\begin{array}{l}\text { Weekly applications @ 62 } \mathrm{g} \mathrm{mat}^{-} \\
{ }^{1} \text { year }^{-1} \text { of Multi-K }\end{array}$ \\
\hline Srinivas (1997) & Robusta & India & $\begin{array}{l}\text { Daily application of Urea up to } \\
180 \text { days }\end{array}$ \\
\hline Berad et al., (1998) & Basrai & India & $\begin{array}{l}\text { Eight equal splits at } 15 \text { days } \\
\text { interval from one month after } \\
\text { planting up to flowering }\end{array}$ \\
\hline Srinivas et al., (2001) & Robusta & India & $\begin{array}{l}\text { On alternate days from } 45 \text { days } \\
\text { after planting till } 320 \text { days }\end{array}$ \\
\hline $\begin{array}{l}\text { Mahalakshmi et al., } \\
\text { (2003) }\end{array}$ & Robusta & India & $\begin{array}{l}\text { At weekly intervals upto } 38 \\
\text { weeks from } 9^{\text {th }} \text { week after } \\
\text { planting }\end{array}$ \\
\hline Guerra et al., (2004) & Prata Ana & Brazil & Monthly fertigation \\
\hline Badgujar et al., (2004) & Grand Naine & India & Weekly Fertigation -38 splits \\
\hline Pinto et al., (2005) & -- & Brazil & $\begin{array}{l}\mathrm{N} \text { and } \mathrm{K} \text { were applied in the } \\
\text { irrigation water three times a } \\
\text { week and Phosphate fertilizers } \\
\text { were applied twice a year. }\end{array}$ \\
\hline Bhalerao et al., (2009) & Grand Naine & India & Weekly Fertigation. \\
\hline $\begin{array}{l}\text { Pawar and Dingre, } \\
(2013)\end{array}$ & Grand Naine & India & $\begin{array}{l}\text { Bi-weekly fertigation-18 splits } \\
\text { 200:40:200 N: } \mathrm{P}_{2} \mathrm{O}_{5}: \mathrm{K}_{2} \mathrm{O} \text { g plant } \\
{ }^{1} \mathrm{crop}^{-1} \text { ) }\end{array}$ \\
\hline $\begin{array}{l}\text { Senthilkumar et al., } \\
\text { (2016) }\end{array}$ & Robusta & India & $\begin{array}{l}\text { Weekly fertigation } \\
\left(200: 110: 200 \mathrm{~N}: \mathrm{P}_{2} \mathrm{O}_{5}: \mathrm{K}_{2} \mathrm{O} \mathrm{g}\right. \\
\left.\text { plant }^{-1} \mathrm{crop}^{-1}\right)\end{array}$ \\
\hline
\end{tabular}




\section{Concentration and distribution of nutrients in banana under fertigation}

According to Srinivas (1997), the nutrient uptake $(\mathrm{N}, \mathrm{P}$ and $\mathrm{K})$ in leaf, stem and rhizome increased with the increase in Nitrogen application above $100 \mathrm{~g}$ plant $^{-1}$ through drip irrigation. Leaf Nitrogen concentration at flowering was higher in the solid soluble fertilizer application as 70\% Nitrogen and 80\% Phoporous and Potassium through drip irrigation. Leaf Nitrogen concentration increased with increasing fertilizer level and moisture availability (Dahiwalkar et al., 2004).

Drip fertigation $(100 \mathrm{~g} N)$ resulted in higher accumulation of nitrogen, phosphorous and potassium as compared to soil application of Nitrogen. Nearly, 35 per cent of total nitrogen, 32 per cent of total phosphorous was accounted for by leaf and around 33 per cent of potassium was accounted for by the root (Srinivas and Raghupathi, 1997). They further opined that the accumulation Nitrogen in leaf, stem and root steadily increased up to 240 days after planting and declined thereafter, whereas decreasing trend was observed in case of phosphorous and potassium accumulation after 180 days after planting in all the plant parts.

Another study by Raghupathi et al., (2000) indicated that the $\mathrm{N}$ and $\mathrm{P}$ concentration was highest in root and was least affected by fertigation. A steady decrease in $\mathrm{N}$ concentration in fruit was noticed as they matured. The $\mathrm{P}$ levels in fruit remained unaffected till maturity. Further they observed that the roots were the greatest repository for $\mathrm{K}$ followed by rhizome and stem and its concentration was highest in fruits during early stages of development and varied widely as fruits matured. On the other hand Costa et al., (2012) reported that the pseudostem is the greatest repository of $\mathrm{K}$.
An experiment with 4 levels of $\mathrm{N}$ and $\mathrm{K}$ through fertigation revealed that the $\mathrm{N}$ uptake was highest with leaves followed by fruits and stems. The P uptake was highest in fruits followed by stems and leaves, whereas $\mathrm{K}$ uptake was highest in fruits followed by leaves and stem (Srinivas et al., 2001). The $\mathrm{N}$ concentration in rhizomes and stem increased with increase in the level of $\mathrm{N}$ fertigation but decreased in roots. Phosphorous concentration was highest in root followed by rhizome and stem. Similar was the case with roots, which was the greatest repository for $\mathrm{K}$ followed by rhizome and stem (Reddy et al., 2002).

The concentration and distribution of secondary and micronutrients in different parts of banana plant including the fruit, sampled at different stages of maturity (from initial stage of development to the final stage of maturity i.e., at 10, 30, 60 and 90 days of maturity) involving fertigation indicated that the pseudostem was the greatest repository for $\mathrm{Ca}$ and $\mathrm{Mg}$. S was evenly distributed in the plant. Bulk of Fe was in the root or stem, while sizeable amount of $\mathrm{Mn}, \mathrm{Zn}$ and $\mathrm{Cu}$ was found mobilized to leaves. The concentrations of $\mathrm{Ca}, \mathrm{Mg}, \mathrm{Fe}, \mathrm{Mn}, \mathrm{Zn}$ and $\mathrm{Cu}$ decreased in fruits with maturity (Raghupathi et al., 2002).

The critical observation by Senthilkumar et al., 2014c on the distribution pattern of secondary and micronutrients indicated that, the calcium and sulphur contents were higher in the pseudostem followed by leaves and fruits whereas, the magnesium content was higher in the pseudo stem followed by fruits and leaves.

The iron content was more in the pseudostem followed by leaves and fruits. On contrary, the zinc and manganese contents were higher in the leaves followed by pseudostem and fruits. The secondary nutrient content was in the order of $\mathrm{Ca}>\mathrm{Mg}>\mathrm{S}$, whereas the micronutrient contents were in the order of 
$\mathrm{Mn}>\mathrm{Fe}>\mathrm{Zn}$ in the leaves, $\mathrm{Fe}>\mathrm{Mn}>\mathrm{Zn}$ in the psuedostem and $\mathrm{Mn}>\mathrm{Fe}>\mathrm{Zn}$ in the fruits.

Increasing $\mathrm{N}$ fertilization significantly increased the uptake of $\mathrm{N}, \mathrm{K}$ and $\mathrm{Mg}$. Increasing $\mathrm{K}$ fertilization significantly increased the uptake of $\mathrm{N}, \mathrm{K}$ and $\mathrm{Ca}$ which was mainly the consequence of increased dry matter production. With $\mathrm{P}$ and $\mathrm{Mg}$ uptake, the decrease in their concentration at higher $\mathrm{K}$ levels offset the effect of increased dry matter (Hegde and Srinivas, 1991).

Fertigation increases the $\mathrm{P}$ uptake efficiency as a result of increased root activity, root distribution, microbial biomass and reduced $\mathrm{P}$ sorption index in the surface soil of banana seedlings (Pan et al., 2011). Nitrate nitrogen at $60 \mathrm{ppm}$ concentration throughout the year recorded greatest plant height in banana cv. Williams with normal leaf nitrogen concentration of 3.17 to 3.93 per cent for optimum yield (Lahav et al., 1982).

Fertilizers applied by fertigation changed the $\mathrm{N}$ and K leaf content (Teixeira et al., 2007). Similarly, Deng LanSheng et al., (2012) observed that the treatment of calcium drip fertigation had some effects on the mineral nutrients concentration with different parts leaf, pseudostem and root of banana.

Among the nutrients, Nitrogen concentration decreased significantly with advancing age and the decrease was more apparent from flower initiation (180 days) to post shooting stage (320 days). Phosphorous concentration was significantly higher at mid vegetative stage, thereafter there was a significant decrease till post-flowering stage. Potassium concentration was highest at mid vegetative stage thereafter it decreased significantly at post flowering stage. Calcium concentration in leaf was lowest in mid vegetative stage. Maximum iron concentration was recorded at flower-initiation stage. The concentration of manganese initially increased in early vegetative stage and subsequently marginal difference was noticed in the concentration. The concentration of zinc showed significant variation at different stages of growth (Raghupathi et al., 2000).

\section{Effect of fertigation on soil chemical properties}

Soil nutrient status (N, P and K) was considerably reduced during the shooting stage. The interaction effect of drip irrigation and fertigation on available $\mathrm{N}$ content was significant both at shooting and harvesting stage of banana cv. Barjahaji (AAA). Available $P$ and $K$ in soil were significantly influenced by drip irrigation and fertigation on shooting and harvesting stage respectively. The treatments viz., drip irrigation $1.00 \mathrm{EpR}$ and $100 \%$ recommended dose of $\mathrm{N}$ and $\mathrm{K}$ through drip resulted in maximum available $\mathrm{N}$ $\left(268.55 \mathrm{~kg} \mathrm{ha}^{-1}, 299.43 \mathrm{~kg} \mathrm{ha}^{-1}\right), \mathrm{P}(73.46 \mathrm{~kg}$ $\mathrm{ha}^{-1}, 74.47 \mathrm{~kg} \mathrm{ha}^{-1}$ ) and $\mathrm{K}\left(85.81 \mathrm{~kg} \mathrm{ha}^{-1}\right.$, $\left.102.40 \mathrm{~kg} \mathrm{ha}^{-1}\right)$ at shooting and harvesting stages respectively (Kotoky et al., 2010).

Nutrient (P, K, Ca and $\mathrm{Mg}$ ) availability and movement in soil profile and some chemical properties (organic matter, $\mathrm{pH}$ and base saturation) were evaluated with $\mathrm{N}$ and $\mathrm{K}$ application through fertigation and conventional fertilization by Teixeira et al., (2007). It was concluded that, both fertigation and conventional fertilization affected soil $\mathrm{pH}$ and exchangeable K. Fertilizers, applied by fertigation or conventional fertilization, increased soil $\mathrm{pH}$ especially in soil layer depth of 0 to $20 \mathrm{~cm}$ and the impact of $\mathrm{pH}$ on fertilization via fertigation was proportional to fertilizer rate. The conventional fertilization also caused a $\mathrm{pH}$ decrease on soil, and it was more intense near the plants, reflecting the effect of fertilizer local application. The application of solid fertilizer on the soil surface determined a significant accumulation 
of exchangeable $\mathrm{K}$ on layers until the depth of $20 \mathrm{~cm}$ and in the region nearer the plant pseudostem.

The effects of fertigation on soil chemical properties were more diffuse because fertilizers were spread in a larger area than the application of conventional fertilization. Edwards et al., (1982) observed that application of $\mathrm{NH}_{4} \mathrm{NO}_{3}$ through drip irrigation system decreased the soil $\mathrm{pH}$ in the top $30 \mathrm{~cm}$. Haynes and swift (1987) concluded that with increasing soil acidification, the leaching of cations viz., $\mathrm{Ca}^{2+,} \mathrm{Mg}^{2+}, \mathrm{K}^{+}$and $\mathrm{Na}$ were also in greater amounts. Soil acidification appeared to inhibit nitrification as levels of $\mathrm{NO}_{3}$ clearly decline below $\mathrm{pH} 5.5$ and at the same time levels of $\mathrm{NH}^{4+}$ increased greatly.

Soil acidification caused by nitrification, occurred to a large extent in the volume of soil immediately below the emitters when fertigated with urea and ammonium sulphate (Haynes and Swift, 1987).

However, acidification was greater at the higher rate of nitrogen and more pronounced with ammonium sulphate than urea. Neilsen et al., (1991) reported a rapid soil acidification beneath the emitter when fertigated with nitrogen and phosphorous and was prominent at higher rates. Changes in soil $\mathrm{pH}$ and cations occurred in soil directly below the emitter with $50 \mathrm{~kg}$ nitrogen per ha per year (Goha and Malkouti, 1992). The soil pH decreased by 1.6 units and the lowest $\mathrm{pH}$ of 4.3 was observed at a depth of $27 \mathrm{~cm}$.

The soil acidification began within a year in a zone extending $60 \mathrm{~cm}$ vertically and horizontally from the emitter and was most severe at $20-30 \mathrm{~cm}$ directly beneath the emitter where the soil $\mathrm{pH}$ decreased from 5.8 to 4.5 after one year and 3.7 after three seasons of $\mathrm{NH}_{4}-\mathrm{N}$ fertigation (Parchomchuck et al., 1993).
The soil samples drawn at $0-0.20 \mathrm{~m}$ and 0.20 $0.40 \mathrm{~m}$ depth and analysed for $\mathrm{pH}$, organic matter, $\mathrm{K}, \mathrm{Ca}$ and $\mathrm{Mg}$ indicated that soil acidification was proportional to the applied $\mathrm{N}$-urea doses and that fertigation reduced the level of soil organic matter. The split application of $\mathrm{K}$ applied through fertigation increased the content of this nutrient in the soil. Soil characteristics varied in the presence of nitrogen and potassium fertigation (Melo, et al., 2012). The interaction effect of drip irrigation and fertigation on organic carbon content in soil was non-significant but the treatments of drip irrigation $1.00 \mathrm{EpR}$ and $100 \%$ recommended dose of $\mathrm{N}$ and $\mathrm{K}$ through drip resulted in maximum organic carbon content (0.57 per cent, 0.63 per cent) at shooting and harvesting stages respectively (Kotoky et al., 2010).

The total nitrogen content of soil decreased with an increase in the soil depth $(15-30 \mathrm{~cm})$ during all growth stages. Application of nitrogen at higher levels in combination with potassium substantially increased the soil nitrogen content (Mahalakshmi, 2000). Anitta and Muthukrishnan (2013) observed that the nitrogen content increased up to $30 \mathrm{~cm}$ and subsequently reduced at $45 \mathrm{~cm}$ under fertigation trials.

According to Suresh and Hasan, (2002), the total nitrogen content in soil decreased with an increase in the soil depth $(15-30 \mathrm{~cm})$ during all the growth stages.

Application of nitrogen at higher levels in combination with potassium substantially increased the soil nitrogen status. Soil nitrogen content was recorded highest with the $\mathrm{N}_{300} \mathrm{~K}_{400}$ treatment. According to Senthilkumar (2014) the nitrogen availability steadily increased up to $30 \mathrm{~cm}$ depth and there after decreased. The available $\mathrm{N}$ content was confined to a depth of $15-30 \mathrm{~cm}$. 
The available soil phosphorus decreases as the depth increases. Generally phosphorus will be higher at the upper surface of the soil as it is less mobile in the soil and tends to accumulate near the point of application i.e., under the dripper, with little being leached downward or laterally (Alwa and Mozzofari, 1995). Senthilkumar (2014) observed that the available phosphorous content in soil was considerably reduced during the shooting and harvest. The phosphorous content at different depths $(0-15 \mathrm{~cm}, 15-30 \mathrm{~cm}$ and $30-45 \mathrm{~cm})$ indicated that the available phosphorous decreased with the increase in the soil depth. The highest available soil phosphorous was confined to $0-15 \mathrm{~cm}$ of the soil layer under all the fertigation treatments. Unlike nitrogen, the higher content of phosphorus was seen at 0 $15 \mathrm{~cm}$ depth than at $15-30 \mathrm{~cm}$ and $30-45 \mathrm{~cm}$. The restricted mobility of phosphorous might be due to its strong reaction as stated by Harjinder singh (2004), as it is less mobile in the soil and tends to accumulate near the point of application ie, under the dripper, with little being leached downward or laterally (Alwa and Mozzofari, 1995).

Suresh and Hasan, (2002) were of the opinion that incorporation of potassium at or above $300 \mathrm{~g} \mathrm{~K}$ plant $^{-1}$ in combination with nitrogen considerably enhanced the available soil phosphorus content. Available phosphorus content in soil was considerably reduced during shooting and harvest.

Application of nitrogen and potassium at the highest level $\mathrm{N}_{300} \mathrm{~K}_{500}$ exhibited maximum (181 ppm) available soil potassium and the increase was nearly 17 per cent over the lowest dose of the nutrient at vegetative stage. Soil available potassium content decreased gradually during shooting and harvest irrespective of soil depth (Suresh and Hasan, 2002). Similarly, the potassium content decreased with the increase in the depth. Majority of the applied potassium through fertigation was held in the surface soil and downward movement was slow which is partially attributed to the net upward flux of soil water in the soil profile as a result of high evapotranspiration (Zeng, 2000; Mmolawa and Or, 2000).

Hasan et al., (1999) reported that the available potassium status of soil was much higher in the surface soil $(0-25 \mathrm{~cm})$ than subsurface soil (25-50cm depth).

The build-up pattern of soil nitrogen was also similar to that of potassium. However, application of potassium showed positive and significant effect on enrichment of soil nitrogen status although available soil phosphorus content was not much influenced by $\mathrm{K}$ application.

With respect to soil available potassium, higher potassium content under fertigation was always found at the depth of $0-15 \mathrm{~cm}$ from the emitter. Suganya et al., (2007) inferred that the available potassium content was at the maximum in the surface layer due to entrance of potassium ions on soil exchange complex resulting in very small movement to deeper layers.

From the above review, it can be concluded that the adoption of fertigation in Banana through application of water soluble fertilizers significantly increases the yield, quality and minimizes the soil pollution.

It also considerably saves water and reduces the requirement of fertilizers per unit area. Most of the results confirmed that $60-80 \%$ of the recommended dose of fertilizers through fertigation would be adequate to obtain yield on par with $100 \%$ recommended dose of fertilizers applied through soil. Thus, beyond doubt fertigation technology is a potential tool to easily double the productivity of banana from the present level of 34.4 tonnes $\mathrm{ha}^{-1}$ in 
India which will not only bring prosperity to the farming community but also fulfil the fruit demand of the country in the near future.

\section{References}

Achilea, O. 1997. Summary of multi-K field experiments conducted in 1996. II. Fruit Trees: Info-Message (Personal communication). p. 3

Alwa, A. K. and Mozzofari. M. 1995. Nitrate leaching in a deep sandy soil as influenced by dry broad cast of fertigation of nitrogen for citrus production. In: International Symposium on fertilization Technology, Israel, 26-31 March 1995, pp: 67-77.

Amritakhound and Bhattacharya, R. K. 2010. Effect of drip irrigation and fertigation on yield and yield attributing characters of banana cv. Barjahaji (AAA). Advances in plant Sci., 23(2): 653-655.

Anonymous. 2013. Horticulture data base, National Horticultural Board, New Delhi.

Anitta, F. S. and Muthukrishnan. P. 2013. Nutrient distribution under drip fertigation systems, World J. Agri. Sci., 9 (3): $277-283$.

Arscott, T. G. 1970. Nitrogen fertilization of banana Musa (Cavendishii Lamber) through a sprinkler irrigation system. Trop. Agric., Trinidad 7(1):17-22.

Ashokkumar, F., Singh, R. K., Singh, A. K., Singh, H. K. and Mishra, A. P. 2007. Effect of fertigation on banana through drip irrigation in NorthBihar, J. Research, 19(1): 81-86.

Ashokkumar, Arvind kumar, Singh, H. K., Kumari, N. and Pramod Kumar. 2009. Effect of fertigation on banana biometric characteristics and fertilizers use efficiency, J. Agril. Engineering 46:12731

Badgujar, C. D., Deshmukh, S. S., Dusane, S. M. and Shide, S. S. 2004. Influence of N and $\mathrm{K}$ fertigation and different plant densities on yield of Banana cv. Grand Naine, South Indian Hort., 52(1/6): 22-28
Berad, S. M., Shinde, S. H. and Dahiwalkar, S. D. 1998. Effects of drip irrigation and paired planting on productivity and economics of banana. J. Maharashtra Agri. Universities, 23(3):288-290.

Bhalerao, V. P., Patil, N. M., Badgujar, C. D. and Patil, D. R. 2009. Studies on integrated nutrient management for tissue cultured Grand Naine banana. Indian J. Agricultural Research, 43(2), 107-112.

Brad Lewis. 2001. Drip irrigation for row crops. Department of Agriculture Co-operating. New Mexico state university (NMSC) Atlanta.

Chandrakumar, S. S., Thimmegowda, S., Srinivas, K., Reddy, B. M. C. and Devakumar. N. 2001. Performance of Robusta banana under nitrogen and potassium fertigation. South Indian Hort., 49(Special):92-94

Choudhary, M. L. 2008. Indian Horticulture in 2020-Challenges ahead-Recent initiatives-soveneir, natl sem - The Horticultural Society of India, NewDelhi

Costa, F. da S., Coelho, E. F., Borges, A. L., Pamponet, A. J. M., Silva, A., dos A. S., Azevedo, M. da, and de, N. F. 2012. Growth, yield and potassium accumulation in 'Galil 18' banana under irrigation and potassium fertilization, Brazil, Pesquisa Agropecuária Brasileira, 47 (3): 409-416.

Dahiwalkar, S. D., Divekar, B. K. and Sonawane. D. A. 2004. Relative performance of fertigation on growth, yield and quality of banana. $J$. Maharashtra Agri. Univ., 29(2):235-237.

Deng LanSheng, Zhang Cheng Lin and Huang LanFen. 2008. Effect of drip nitrogen fertigation on growth of banana J. South China Agri. Univ., 29(1):19-22

Deng LanSheng, Tu PanFeng, Gong Lin, Ye QianQian, Chen Kang and Li ZhongHua. 2012. Effect of calcium treatment by means of drip fertigation on growth and absorption of mineral nutrients in banana. Acta Agriculturae Universitatis Jiangxiensis, 34(1): 34-39.

Deolankar, K. P and Firake, N. N. 2001. Effect 
of Water soluble fertilizers on growth and yield of Banana, J. Maharastra Agric. Univ., 26(3): 333-334.

Dineshkumar, Pandey, V. and Vishal Nath. 2012. Growth, yield and quality of vegetable banana Monthan (Banthal ABB)in relation to NPK fertigation, Indian J. Hort., 69(4): 467-471.

Edwards, J. H., Bruce, R. R., Horton, B. D., Chesness, J. L. and Wehunt, E. J. 1982. Soil cation and water distribution as affected by $\mathrm{NH}_{4} \mathrm{NO}_{3}$ applied through a drip irrigation system, J. Amer. Soc. Hort. Sci., 107:1142-1148.

Goha, K. M. and Malkouti, M. I. 1992. Preliminary nitrogen, phosphorous, potassium, calcium and magnesium DRIS norms indicies for apple orchards in canter burg, Newzeland Rev, Indust. Agric., 49: 15-21.

Goldberg, D. and Shmueli, M. 1970. Drip irrigation a method used under arid and desert conditions of high water and soil salinity. Trnas. Amer. Soc. Agric. Engg., 13:38-41.

Guerra, A. G., Zanini, Jose, R., Natale, William, Paveni and Luizc. 2004. Frequency of fertigation with nitrogen and potassium applied by microsprinkler system on Prata-Anã banana plant. J. Brazilian Association of Agri. Engineering, 24(1): 80-88.

Guerrero, R. R. and Gadbau, R. 1996. Banana response to different potassium sources in fertigation, Cienaga, (Magdalena), Colombia. IFA-PPI Regional Conference for Latin America and the Caribbean workshop. Lismore, New South Wales. 134-158.

Harjinder Singh, N. K., Narda and Chawla, J. K. 2004. Effect of irrigation frequency in sub surface irrigated vegetables, Hort. Tech, 13:15-20

Hasan, M. A., Suresh, C. P., Sonali Bhattacharya and Chattopadhyay, P. K. 1999. Influence of potassium on the soil nutrient status of banana orchard, Environment and Ecology, 17(3): 577579.
Haynes, R. J. and Swift, R. S. 1987. Effect of trickle fertigation with three forms of nitrogen on soil $\mathrm{pH}$, levels of extractable nutrients below the emitter and plant growth. Plant and soil, 102:211-221.

Haynes, R. J. 1985. Principles of fertilizer use for trickle irrigated crops. Fert. Res., 6:235-255

Hegde, D. M. and Srinivas, K. 1989. Growth, yield, nutrient uptake and water use of banana crops under drip and basin irrigation with $\mathrm{N}$ and $\mathrm{K}$ fertilization. Trop. Agric., (Trinidad), 68(4):331-334.

Hegde, D. M. and Srinivas, K. 1991. Growth, yield, nutrient uptake and water use of banana crops under drip and basin irrigation with N\&K fertilization, Trop. Agric., (Trinidad), 68(4): 339-334.

Kavino, M., Kumar, N. and Ponnuswamy, V. 2002. Effect of source of fertilizers for fertigation on yield and quality of banana cv. Robusta (AAA). South Indian Hort., 50:301-307

Kotoky, U., Khound, A., Bhattacharyya, R. K., Devee, A. and Baruah, M. 2010. Effect of irrigation and fertigation on soil parameters of banana cv. Barjahaji, Hort. J., 23(1): 18-21

Kumaran, S. S. and Muthuvel, I. 2009. Fertigation in second generation T. C. banana variety suited to semi-arid ecosystems. J. Ecobioology, 24(3):245250.

Lahav, E., Turner, D. W. and Weir, R. 1982. The effect of the amount and form of nitrogen on the growth, yield and chemical composition of the Williams banana. International banana Nutrition Newsletter. No (5): 22-23.

Lahav, E. and Kalmar, D. 1988. Response of banana to drip irrigation, water amount and fertilization regimes. Commun. Soil Sci. Plant Anal., 19: 28-46.

Lahav, E. and Kalmar, D. 1995. Fertigation and water regimes on a banana plantation. In: Dahlie Greidinger international symposium on fertigation. TechnionIsrael Institute of technology, Haifa, Israel, 26 Marcy - 1 April 1995. 325-332. 
Lopez, A. and Espinosa, J. 1998. Banana response to potassium. Better Response International, 12(1): 1-5.

Magar and Bhambure, C. V. 2000. Drip irrigation and fertilization technology for higher production of horticultural crops (In) Sovenir, Natl. Sem., Hi-tech Horticulture, National Academy of Agricultural Sciences, New Delhi, pp. 3644.

Magen, H. 1995. An overview of some practical aspects, Fert. News, 40:97-100

Mahalakshmi, M. 2000. Water and fertigation management studies in banana cv. Robusta (AAA) under normal planting and high density planting systems, Ph. D Thesis submitted to the Tamil Nadu Agricultural University, Coimbatore-3

Mahalakshmi, M., Kumar, N., Jayakumar, P., Soorianathasundaram, K. 2001. Fertigation studies in banana under normal system of planting. South Indian Hort., 49(Special): 80-85.

Mahalakshmi, M., Kumar, N., Soorianathasundaram, K. 2003. Effect of fertigation and irrigation on the yield of high-density plantations of cv. 'Robusta'. Infomusa, 12(1): 42-44.

Mahendran, P. P., Yuvaraj, M., Parameswari, Gurusamy, C. A. and Krishnasamy, S. 2013. Enhancing growth, yield and quality of banana through subsurface drip fertigation. International J. Chemical Environmental and Biological Sci., 1(2): 391-394.

Melo, A. S. de, Sobral, L. F., Brito, M. E. B., Fernandes, P. D., Suassuna, J. F. and Viégas, P. R. A. 2012. Chemical attributes of an Ultisol cultivated with banana crop fertigated with $\mathrm{N}$ and $\mathrm{K}$, Revista Brasileira de Ciências Agrárias,, 7(4): 562-568.

Mmolawa, K. and Or, D. 2000. Root zone solute dynamics under drip irrigation: A review, Plant and soil, 222:163-190

Mustaffa, M. M and Kumar, V. 2012. Banana production and productivity enhancement through spatial, water and nutrient management. J. Hort. Sci., 7(1):1-28.
Naira Ashraf, Sharma, M. K. and Bhat, M. Y. 2012. Micro-irrigation and fertigation in fruit trees - a review, Environment and Ecology, 30(4): 1252-1257.

Nanda, R. S. 2010. Fertigation to enhance farm productivity, Indian J. Fertilisers, 6(2): 13-16, 19-22.

Neilsen, G. H., Parchomchuck, P. and Hogue, E. J. 1991. Nitrogen and phosphorous fertigation of newly planted apple trees, Hort. Sci., 26:784.

Noor, U. N. M., Kazi Suleman Memon, Rahell Anwar, Saeed Ahmad and Muhammad Nafees. 2010. Status and response to improved NPK Fertilization practices in banana. Pak. J. Bot., 42(4): 2369-2381.

Pan, N., Sten, H., Wu, D. M., Beng, L. S., Tu, P. F., Gan, H. H. and Liang, Y. C. 2011. Mechanism of improved phosphate uptake efficiency in banana seedlings on acidic soils using fertigation. Agric. Water Management, 98 (4).

Pandey, S. D., Jeyabaskaran, K. J., Laxman, R. H. and Mustaffa, M. M. 2001. Effect of different moisture regimes and $\mathrm{N}$ fertigation on growth, yield and quality of Poovan banana. Prog. Hort., 33(2): 130133.

Pandit, S. N., Mandal, B. K. and Singh, V. R. 2011. Growth, yield and quality of dwarf cavendish banana in relation to $\mathrm{N}, \mathrm{P}, \mathrm{K}$ fertigation. MKK Publication, Kolkata, India, Environment and Ecology, 29(2A): 860-863.

Parchomchuk, P., Neilsen, G. H. and Hogue, E. J. 1993. Effect of drip fertigation of $\mathrm{NH}_{4}-$ $\mathrm{N}$ and $\mathrm{P}$ on soil $\mathrm{pH}$ and cation leaching, Can. J. soil Sci., 73: 157-164.

Pawar, D. D and Dingre, S. K. 2013. Influence of fertigation scheduling through drip on growth and yield of banana in western Maharashtra, Indian J. Hort., 70(2): 200205.

Pinto, J. M., de Faria, C. M. B., Silva, D. J. and Feitosa Filho, J. C. 2005. Nitrogen and potassium doses through fertigation on banana crop. Irriga, 10(1): 46-52.

Radha, T. and Mathew, L. 2007. Banana, In: Fruit crops, New India Publishing agency, 
Pitam pura, New Delhi, pp-33-58.

Raghupathi, H. B., Srinivas, K., Reddy, B. M. C. and Padma, P. 2000. Concentration and distribution of primary Nutrient in Banana under fertigation. Indian J. Hort., 57(3).

Raghupathi, H. B., Srinivas, K. and Reddy, B. M. C. 2002. Concentration and distribution of secondary and micro nutrients in banana under fertigation, South Indian Hort., 50 (4/6): 291-300.

Raskar, B. S. 2003. Effect of planting technique and fertigation on growth, yield and quality of banana (Musa spp.), Indian J. Agron., 48(3):235-237.

Reddy, B. M. C., Srinivas, K., Padma, P. and Raghupathi, H. B. 2002. Response of Robusta banana to $\mathrm{N}$ and $\mathrm{K}$ fertigation. Indian J. Hort., 59(4): 342-348.

Rivera, R. A. 2004. Banana Production and Marketing. A report prepared by Agronomist, Philippines.

Robinson, J. C. 1996. Bananas and plantains. Institute for tropical and subtropical crops. Nelspruit, South Africa.

Sanjit Pramanik, Ray, R. and Hirak Banerjee. 2013. Performance of banana cv. Martaman (AAB, silk) under drip fertigation system in new alluvial zone of West Bengal, Crop Res., (Hisar), 46 (1/3): 153-161.

Santos, dos, V. P., Fernandes, P. D., de, A. S., Melo, Sobral, L. F., Brito, M. E. B., J. D. de M. Dantas, and Bonfim, L. V. 2009. Fertigation of banana CV Prata Anã with $\mathrm{N}$ and $\mathrm{K}$ in an Ultisol. Revista Brasileira de Fruticultura, 31(2): 567-573

Sathya, S., James Pitachi, G., Indirani, R. and Kannathasan, M. 2008. Effect of fertigation on availability of nutrient $(\mathrm{N}$, $\mathrm{P} \& \mathrm{~K})$ in soil-A review, Agric. Rev., 29(3): 214-219.

Senthilkumar, M. 2014. Enhancing growth and yield of Banana cv. Robusta (AAA) through fertigation with consortium of biofertilizers. Ph. D Thesis submitted to the Gandhigram Rural Institute (Deemed University), Dindigul, Tamilnadu, India

Senthilkumar, M., Ganesh, S., Srinivas, K. and
Panneerselvam. P. 2014a. Influence of fertigation and consortium of Biofertilizers on photosynthesis, chlorophyll content, Yield parameters and yield of banana cv. Robusta (AAA). Plant Archives, 14 (1): 387-391.

Senthilkumar, M., S. Ganesh, K. Srinivas and P. Panneerselvam. 2014b. Integration of fertigation and consortium of Biofertilizers and their effects on quality attributes of banana cv. Robusta (AAA) Plant Archives, 14(1): 401-404.

Senthilkumar, M., Ganesh, S., Srinivas, K. and Panneerselvam. P. 2014c. Enhancing Uptake of Secondary and Micronutrients in Banana Cv. Robusta (AAA) Through Intervention of Fertigation and Consortium of Biofertilizers. Sch. Acad. J. Biosci., 2(8): 472-478.

Senthilkumar, M., Ganesh, S., Srinivas, K., Panneerselvam. P. and Kasinath, B. L. 2016. Combining fertigation and consortium of bio-fertilizers for enhancing growth and yield of banana cv. Robusta (AAA), Indian J. Hort., 73(1), March 2016: 36-41

Shahar, G. and Achilea, O. 1997. Enhance your banana with multi-K. Haifa Chemicals Ltd., Israel. (Personal Communication).

Singh, H. P. 2007. National and International Scenario of Banana and Plantain. In: Banana: Technological Advancements. Singh, H. P. and S. Uma. (Eds.) pp1-19

Sivanappan, R. K. 1985. In: Drip irrigation in action, vol. II ASAE, Michigan, pp-736740

Smith, B. L. 1991. Fertilization of Mango. Citrus and sub-tropical fruit research station, Nelspruit, South Africa.

Smith, B. L. 1992. Effect of applying $\mathrm{KNO}_{3}$ and banana through microjets and drippers. Banana Newsletter, 15: 23.

Smith, B. and Hoffman, E. 1998. Comparing drip and micro-spray fertigation. Weltropika Bulletin., 302: 14-16. Hort. Abstr., 5550.

Solaimalai, A., Baskar, M., Sadasakthi, A. and Subburamu. K. 2005. Fertigation in high value crops- A review. Agric. Rev., 26(1): 


\section{$1-13$}

Sneh, M. 1995. The history of fertigation in Israel. Int. Water. Irrg. Rew, 15:17-20.

Solia, B. M., Aklade, S. A., Patil, S. J., Patel, A. P., Malik, M. S., Dhimmar, S. K. and Patil, R. G. 2010. Studies on efficient use of water and nutrients in banana under South Gujarat conditions, Green Farming, 1(1): 59-61.

Sousa, de, V. F., da, M. E., Veloso, C., L. Vasconcelos, L. F., Ribeiro, V. Q., de Souza, V. A. B. and d'Albuquerque Junior, B. S. 2004. Nitrogen and potassium applied by fertirrigation on the yield characteristics of banana 'Grand Naine' Pesquisa Agropecuária Brasileira, 39 (9): 865-869.

Srinivas, K. and Raghupati. H. B. 1997. Nutrient Partitioning in 'Neypoovan' Banana under Nitrogen fertigation. Indian J. Hort., 54 (2)

Srinivas, K. 1997. Growth, Yield and quality of banana in relation to $\mathrm{N}$ fertilization, Tropical Agri., (Trinidad), 74(4): 260264.

Srinivas, K., Reddy, B. M. C., Kumar, S. S. C., Gowda, S. T., Raghupati, H. B. and Padma. P. 2001. Growth, Yield and nutrient uptake of Robusta banana in relation to $\mathrm{N} \& \mathrm{~K}$ fertigation, Indian $\mathrm{J}$. Hort., 58(4): 287-293

Suganya, S., Anitha, A. Appavu, K. 2007. Moisture and nutrient distribution system under drip fertigation sytems. In: Third international ground water conference on "water environment and Agriculture present problems and future challenges" pp 7-10

Suresh, C. P. and Hasan. M. A. 2002. Soil nutrient status of a banana (Musa AAA, sub-group Cavendish, cv. Giant Governor) plantation in relation to nitrogen and potassium nutrition. Crop Res., (Hisar), 23 (3): 457-462.

Swennen, R. 1990. Plantain cultivation under West African conditions. A reference manual. International Institute of Tropical Agriculture, Ibadan, Nigeria. 24-26

Thangaselvabai, T., Suresh, S., Joshua, J. P. and Sudha, K. R. 2009. Banana nutrition - A review, Agri. Reviews, 30 (1): 24-31.

Teixeira, L. A. J., Natale, W., Bettiol Neto, J. E. and Martins, A. L. M. 2007. Nitrogen and potassium application on banana plant by fertirrigation and conventional fertilization - soil chemical properties. Revista Brasileira de Fruticultura, 29(1): 143-152.

Teixeira, L. A. J., Quaggio, J. A. and Mellis, E. V. 2011. Enhancing nutrient use efficiency in banana due to irrigation and fertigation. Revista Brasileira de Fruticultura, 33(1): 272-278.

Wichmann, W. 1992. World Fertilizer Use Manual. International Fertilizer Industry Association, Paris, France.

Young, S. C. H., Summis, T. W. and Wu. I. P. 1985. Banana yield as affected by deficit irrigations and pattern of lateral layouts. Trans. ASAE, 28: 507-570.

Zeng, D. R., Brown, P. H. and Holtz. B. A. 2000. Potassium fertigation improves soil $\mathrm{K}$ distribution, Builds pistachio yield and quality. Fluid J., pp: 1-2

\section{How to cite this article:}

Senthilkumar, M., S. Ganesh, K. Srinivas, P. Panneerselvam, A. Nagaraja and Kasinath, B.L. 2017. Fertigation for Effective Nutrition and Higher Productivity in Banana- A Review. Int.J. Curr.Microbiol.App.Sci. 6(7): 2104-2122. doi: https://doi.org/10.20546/ijcmas.2017.607.248 